\section{Pat Patterson}

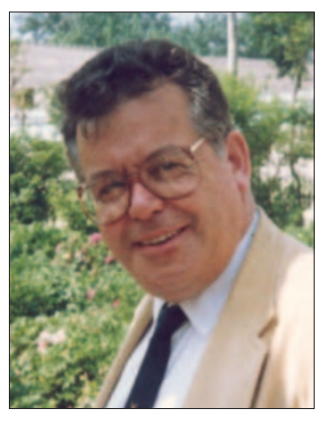

Dr Pat Patterson, former Head of the BDA's Salaried Services Department, died after a period of ill health on 5 April 2005, just a month short of his 70th birthday.

Pat, who joined the BDA in 1976, was distinctive from the start, with a longer string of letters after his name than anyone else at the BDA. He left school at a time when Harold Wilson was promising a white hot technological revolution and a glittering future for anyone going into science. Like many people of his generation, reality was different and he had to give up research in order to feed his family. He joined the BDA from a long-defunct quango, NRDC, where he negotiated contracts between inventors and manufacturers to bring innovations to market. His passport ought to have given 'negotiator' as his occupation.

Although failing to give Pat a continuing career in science, Harold Wilson gave him something else - a batch of 1970s legislation on employment protection and union recognition which allowed him to build up from nothing the BDA's representation of individual members in salaried employment. Pat always seemed the most focused person at Wimpole Street. 'My job is to look after the members,' he'd say, when attempts were made to distract him. It wasn't always clear exactly what this meant - the trouble with representing individual members is that the work is necessarily confidential so it didn't get cheers at committees. But the members looked after by Pat, in disciplinary or redundancy cases, had good reason to be grateful for his determination. He helped so many, including those affected by the closure of the Edinburgh Dental School and the Royal and University College Hospital Dental Schools in London.

\section{Bob McKechnie}

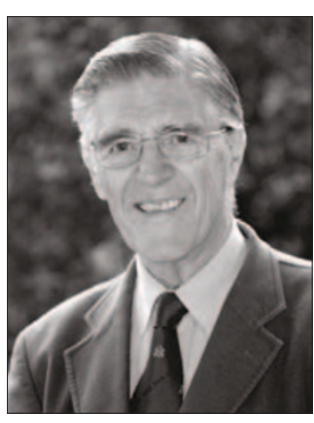

It was with a sense of shock that the profession in the West of Scotland learned of the sudden death of Robert (Bob) McKechnie, aged 79, on 23 June 2006 while on holiday with his wife Beth in France.

Educated at Kilmarnock Academy, Bob qualified in 1949 in Glasgow. After two years in the RAF Dental Branch, he became a Community Dental Officer in Bournemouth. Eighteen months later he returned to his ain folk and joined the Renfrew County Council CDO service. He really enjoyed treating children and specialised in orthodontics. In 1960 he was awarded the Diploma in Dental Orthopaedics. Bob's administrative skills were recognised when he was appointed Chief Dental Officer in 1961, and in 1969 was appointed County Orthodontist.

In 1974 Bob became the first Chief Administrative Dental Officer of the Greater Glasgow Health Board. Modest and unassuming, he showed great skill in balancing the needs and demands of the various branches of the profession, and it was largely due to his diplomacy that excellent relations existed between the dental and medical professions in Glasgow.

The BDA was an important part of Bob's life. He acted as Secretary of the West of Scotland Branch from 1968-79 and was President of the Branch in 1979. He was a member of the Representative Board for 22 years and was elected to Council, on which he served for five years. He was Chairman of BDA Scottish Council from 1978-84.

\section{His legacy of support for members goes from strength to strength}

Pat was involved in the establishment of the autonomous committees at the BDA in the 1970s and from then was active with all the salaried groups. He was party to the establishment of the Clinical Academic Staff Salaries Committee in 1978 and the agreement in 1979 on parity for Clinical Academics with their NHS colleagues. This was a major achievement for both the BMA and BDA in which he played a big part. He worked closely with the BMA over clinical academic and armed forces issues and with them and other staff side organisations through the General Whitely Council. He had a particular interest in superannuation and also supported his work colleagues in this issue as well as BDA members. He nurtured the BDA Dentsply Student Clinician Programme which today is a prestigious event involving all the UK dental schools. He loved to travel and was an outstanding success as the leader for the $B D J$ Study Tours to both China and Kenya.

Pat had been a feature of BDA life for so many years and as a manager had the ability to identify talent in his team members and would ensure that they were given the chance to achieve their full potential. The legacy of support for individual members, and the network of local representatives which he established, still goes from strength to strength.

Pat retired in 1999 but ill health sadly dogged the latter years of his life and he was unable to enjoy fully the retirement he had planned so carefully. He was a devoted family man, intensely proud of his wife Joan and their two sons, Daniel and Robert, and it is to them we extend our deepest sympathies.

S. Osborne

\section{He showed great skill in balancing the needs and demands of the profession}

During this time he was a member of the Central Committee for Community Dental Services and was President of the British Association for the Study of Community Dentistry from 1986-87. In recognition of his services to the profession, Bob was awarded the FDS of the Royal College of Physicians and Surgeons of Glasgow in 1990 and in 1992 was granted Life Membership of the BDA. In 2001 the Association honoured him once more when he was elected a Fellow.

Bob retired formally in 1991, but his commitment to the profession continued - he was a member of the Benevolent Fund Executive and local representative of the Fund. He was instrumental in setting up - and organising - the seniors section of the Branch, wherein retired dentists meet every two months. An additional interest was the history of dentistry, and he was elected to be President of the Lindsay Society in 2007, a post he will now sadly not fulfil.

Bob was extremely well read, a keen gardener and DIY man. Very much a family man, he was very proud of his children and grandchildren. He is survived by Beth, his wife for 52 years, his daughters Sheila, Aileen and Fiona, and his four granddaughters, to whom we extend our sincere condolences. He will be remembered by all who knew him as a likeable, caring man - he was truly one of those rare individuals of whom it can be said that no-one ever said a bad word.

B. Caplan 